\title{
Respiratory mechanical properties during fentanyl and alfentanil anaesthesia
}

\author{
P.P. Ruiz Neto MD PhD,* J.O.C Auler Jr. MD PhD $†$
}

The purpose of this study was to assess the effects on respiratory mechanics of fentanyl and alfentanil in 20 subjects to be submitted to coronary artery bypass grafting. Using the end inflation occlusion method (EIOM) we obtained the elastance $(E)$ and resistance $(R)$ of the total respiratory system $\left({ }_{r s}\right)$, thoracic wall $\left(_{w}\right)$ and lungs $(\mathcal{L})$. The total respiratory system was divided into thoracic wall and lungs by using an oesophageal catheter. The data were recorded before, immediately after, and two, five and ten minutes after fentanyl and alfentanil iv bolus, at doses of 30 and $120 \mu \mathrm{g} \cdot \mathrm{kg}^{-1}$, respectively. The Ers increased at two, five and ten minutes and the $E_{L}$ at ten minutes after drug administration. The $R_{r s, \min }$ and $R_{L \text { min }}$ increased at two, five and ten minutes and the $R_{L \text { max }}$ at five and ten minutes. Both drugs provoked no change in Ew or $R w$. It is concluded that the increases in $R_{r s, \min }$ and $R_{L, \text { min }}$ could be explained by opioid bronchoconstriction. No differences were found between the effects of fentanyl and alfentanil on respiratory mechanics.

Le but de la présente étude est d'évaluer les effets du fentanyl et de l'alfentanil sur la mécanique ventilatoire de patients devant subir un pontage aorto-coronarien sous anesthésie générale. Les patients sont distribués de façon aléatoire en un groupe fentanyl $(n=10)$ et un groupe alfentanil $(n=10)$. L'élastance $(E)$ et la résistance $(R)$ des poumons $(L)$, de la cage thoracique (W) et de tout le système mécanique ven: tilatoire (rs) sont déterminés par des mesures faites en fin d'inspiration après occlusion des voies aériennes. Un cathéter oesophagien branché à un manomètre est utilisé pour évaluer la pression pleurale, afin de permettre le calcul des paramètres de chacune des composantes du système mécanique ven-

\section{Key words}

ANAESTHETICS, INTRAVENOUS: alfentanil, fentanyl; VENTILATION: respiratory mechanics.

From the Departments of Anesthesiology, *Instituto Central and †nstituto do Coração do Hospital das Clinicas da Faculdade de Medicina da Universidade de São Paulo, Brazil. Address correspondence to: Dr. P.P. Ruiz Neto, Alameda Lorena, 853-21B, São Paulo - SP, 01424, Brazil. Accepted for publication 26th January, 1992. tilatoire. Les mesures sont faites avant, immédiatement après, puis 2,5 et 10 minutes après l'injection rapide de fentanyl 30 $\mu \mathrm{g} \cdot \mathrm{kg}^{-1}$ ou d'alfentanil $120 \mu \mathrm{g} \cdot \mathrm{kg}^{-1}$. Les résultats démontrent que $E_{r s}, R_{r s, m i n}$ et $R_{L, m i n}$ augmentent 2, 5 et 10 minutes après l'administration de fentanyl ou d'alfentanil. Les deux narcotiques causent une augmentation similaire de $E_{L} 10$ minutes après leur injection et de $R_{L, \max } \grave{a}$ partir de 5 minutes suivant leur administration. Les deux agents sont dépourvus d'effet sur $E_{w}$ et $R_{w}$. En conclusion: 1) le fentanyl et l'alfentanil ont des effets comparables sur la mécanique ventilatoire;2) les augmentations de $R_{r, \text { min }}$ et $R_{L_{\text {min }}}$ sont probablement dues à un effet constrictif des narcotiques sur les muscles lisses bronchiques.

Milic-Emili et al. ${ }^{1}$ have suggested that the use of the end inflation airway occlusion method (EIOM) during constant-flow inflation allows a comprehensive understanding of the actions of general anaesthetics on static elastance $\left(E_{r s}\right)$ and resistance $\left(R_{r s}\right)$ of the respiratory system.

Taeger et al. ${ }^{2}$ reported that a high percentage of fentanyl and alfentanil was sequestrated in the lung after $i v$ administration. They suggested that the binding sites could be located in alveolar surfactant. On the other hand the action of opioids on smooth bronchial muscles is to cause bronchoconstriction. $^{3}$

Although the actions of opioids on the cardiovascular system are well described, little information is available on their effects on respiratory mechanics. Considering the pulmonary kinetics of opioids and their possible effects on bronchial smooth muscle, we investigated the effects of $i v$ fentanyl and alfentanil on respiratory mechanics in patients submitted to cardiac surgery.

\section{Methods}

After approval by our hospital ethics committee and patients' informed consent, we studied 20 randomly selected patients scheduled for elective coronary artery bypass surgery. Patients aged less than $60 \mathrm{yr}$, without previous thoracic surgery or deformity, with no acute or chronic pulmonary disease, and in absence of obesity assessed by the mass body index, who belonged to Group I or II of the 


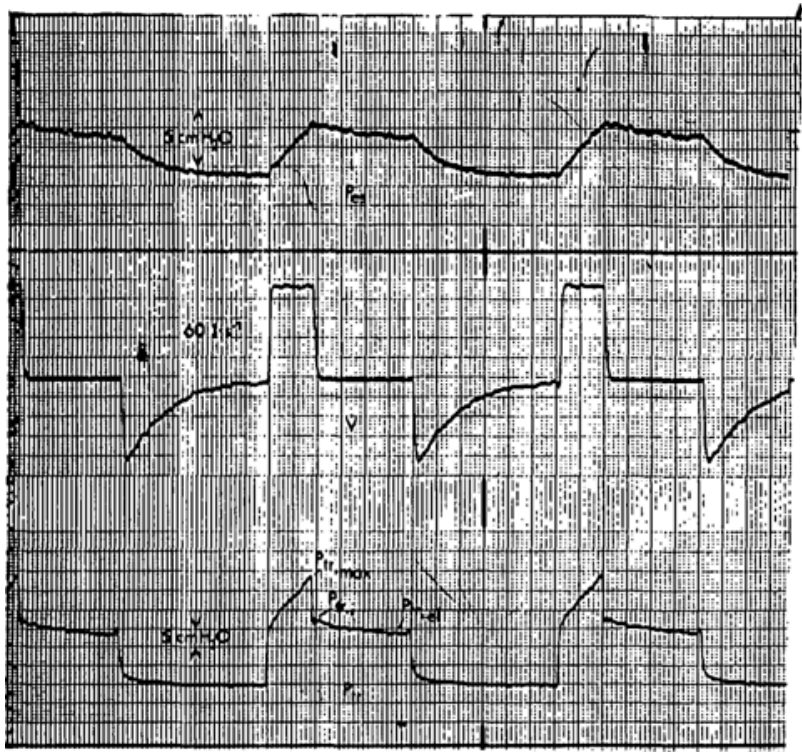

FIGURE I Detail of the tracings obtained from one patient. From top to bottom: tracings of oesophageal pressure $\left(\mathrm{P}_{\mathrm{es}}\right)$, flow ( $\left.\mathrm{V}\right)$, tracheal pressure $\left(\mathrm{P}_{\mathrm{t} r}\right) . \mathrm{P}_{\mathrm{tr} \text { max }}$ tracheal pressure immediately before endinspiration airway occlusion. $P_{t r . j}$ indicates the end of the rapid drop of tracheal pressure. $P_{t r . c t}$ indicates the plateau of the tracheal pressure.

New York Heart Association and the Canadian Cardiovascular Society were entered into the study.

Patients were randomly divided into two groups of ten subjects according to the opioid to be studied. Premedication consisted of midazolam $15 \mathrm{mg}$ po, one hour before surgery. Monitoring consisted of invasive arterial and central venous blood pressure measures and ECG. After midazolam $0.3-0.4 \mathrm{mg} \cdot \mathrm{kg}^{-1} i v$, tracheal intubation was facilitated by pancuronium bromide $0.12 \mathrm{mg} \cdot \mathrm{kg}^{-1} i v$. The lungs were ventilated using a Bear 5 ventilator (Bear Med. Systems, Inc. Riverside, CA, USA) set to provide a tidal volume of $12 \mathrm{ml} \cdot \mathrm{kg}^{-1}$ and a respiratory rate of 10 cycles $\cdot$ min $^{-1}$ with an $\mathrm{FIO}_{2}$ of 1.0. Arterial blood samples were withdrawn to measure $\mathrm{PaO}_{2}$ and $\mathrm{PaCO}_{2}$, which remained within normal limits. Pleural pressure $\left(\mathrm{P}_{\mathrm{pl}}\right)$ was estimated from oesophageal pressure $\left(\mathrm{P}_{\mathrm{es}}\right)$. A polyethylene catheter (ID $1.4 \mathrm{~mm}$, length $100 \mathrm{~cm}$ ) with a multiperforated extremity sealed by a $12 \mathrm{~cm} \times 4.0 \mathrm{~cm}$ latex balloon was placed in the oesophageal lumen. The oesophageal catheter was fixed at the point where the maximal variation of oesophageal pressure was achieved, and a constant rate of rise in oesophageal pressure was recorded during positive-pressure ventilation.

The balloon was filled with 0.5 to $1.0 \mathrm{ml}$ of air and oesophageal pressure was measured by a Hewlett-Packard $1280 \mathrm{C}$ pressure transducer. The volume-pressure curve of the balloon was flat between $0.2-5.0 \mathrm{ml}$. Once $P_{e s}$ was measured, the respiratory system was divided into two components, chest wall and lungs, as described by Behrakis et al. ${ }^{4}$ Signals of tracheal pressure and flow were obtained on line from the ventilator and recorded on a Hewlett-Packard HP 7700 pen recorder. Tidal volume $\left(V_{T}\right)$ was obtained by electronic integration of the flow (V) signal (see Figure 1).

Airway occlusion at end-inspiration was performed setting an inspiratory pause of two seconds to the ventilator. Inspiration always began from the elastic equilibrium point of the respiratory system with all pressure and flow tracings returning to the base line.

Elastance of the respiratory system $\left(\mathrm{E}_{\mathrm{rs}}\right)$ was calculated by dividing the end-inspiratory plateau pressure (respiratory system elastic recoil pressure $-\mathrm{P}_{\mathrm{el}, \mathrm{rs}}$ ) by tidal volume, or $P_{\mathrm{el}, \mathrm{rs}} / \mathrm{V}_{\mathrm{T}}$. Similarly, chest wall elastance $\left(\mathrm{E}_{\mathrm{w}}\right)$ was obtained from $\mathrm{P}_{\text {el,es }} / \mathrm{V}_{\mathrm{T}}$. Lung elastance $\left(\mathrm{E}_{\mathrm{L}}\right)$ was obtained subtracting $E_{w}$ from $E_{r s}$.

The respiratory system resistance $\left(R_{r s, \max }\right)$ was calculated from the analysis of EIOM,$^{5}$ by dividing the difference of peak tracheal pressure $\left(P_{\text {tr,max }}\right)$ and $P_{\text {el,rs }}$ by the flow $(\dot{V})$ immediately before occlusion. Chest wall resistance $R_{w, \max }$ was equal to $\mathrm{P}_{\mathrm{es}, \max }-\mathrm{P}_{\mathrm{el}, \mathrm{es}} / \dot{\mathrm{V}}$. Lung resistance $R_{L, \text { max }}$ was calculated by subtracting $R_{w, \max }$ from $R_{r, \max }$.

The EIOM allows the respiratory resistance to be studied by dividing it into two subcomponents. The homogeneous subcomponent, $\mathrm{R}_{\mathrm{r}, \mathrm{min}}$ or $\mathrm{R}_{\mathrm{int,rs}}{ }^{1}$ is associated with frictional forces developed during gas flow in the central airway. It can be calculated from the first of the two-step decrease in pressure observed after endinspiratory airway occlusion, or $\left(\mathrm{P}_{t r, \max }-\mathrm{P}_{\mathrm{tr}, \mathrm{i}}\right) \dot{\mathrm{V}}$. From $P_{t r, i}$, tracheal pressure decay decreases until $P_{e l, r s}$ is reached. This second step results from stress relaxation and pendelluft, which are mechanisms existing within the lung parenchyma. They are associated with non-homogeneous respiratory resistance, $\mathrm{R}_{\mathrm{rs}, \mathrm{u}}$ or $\Delta \mathrm{R}_{\mathrm{rs}}{ }^{\prime} \mathrm{R}_{\mathrm{rs}, \mathrm{u}}$ is expressed by $\left(\mathrm{P}_{\mathrm{tr}, \mathrm{i}}-\mathrm{P}_{\mathrm{el}, \mathrm{rs}}\right) \dot{\mathrm{V}}$. The same mathematical treatment was performed with oesophageal pressure, obtaining resistance values for chest wall $\left(R_{w, \min }\right.$ and $\left.R_{w, u}\right)$. Subtracting the resistance subcomponents of the chest wall from respiratory system subcomponents, values of lung resistances $\left(R_{L, \min }\right.$ and $\left.R_{L, u}\right)$ can be obtained.

After orotracheal intubation, manual pulmonary hyperexpansion was performed to avoid atelectasis before commencing the investigation. The values of the equipment resistance were subtracted and the results represent patients' intrinsic values for resistance and elastance, excluding the upper airways. To calculate the elastance of the equipment, the breathing circuit was occluded and a known amount of air was injected into the system. The increasing pressure of the breathing system, $P_{\text {equip }}$, was recorded. The ratio between $P_{\text {equip }}$ and the volume injected provided the elastance of the equipment. 
TABLE 1 Coefficients of the function relating $P_{\text {res }}$ and flow and values of resistive pressure to be subtracted from the tracheal tubes plus connectors used

\begin{tabular}{lllll}
\hline $\begin{array}{l}\text { Tracheal tube } \\
(\mathrm{mm})\end{array}$ & $a$ & $b$ & $r$ & $\begin{array}{l}F \\
\left(\mathrm{~cm} \mathrm{H}_{2} \mathrm{O}\right)\end{array}$ \\
\hline 8.0 & 0.83 & 1.65 & 0.996 & 6.44 \\
8.5 & 0.80 & 1.63 & 0.997 & 6.02 \\
9.0 & 0.79 & 1.61 & 0.997 & 5.88 \\
\hline
\end{tabular}

$r$ - Coefficient of correlation of the function relating $P_{\text {res }}$ and flow.

$\mathrm{F}-$ Value of the resistive pressure at $1.0 \mathrm{~L} \cdot \mathrm{sec}^{-1}$ to be subtracted.

TABLE II Demographic data

\begin{tabular}{|c|c|c|c|c|c|c|}
\hline & \multirow{2}{*}{$\begin{array}{l}\text { Age } \\
(y r)\end{array}$} & \multicolumn{2}{|c|}{ Sex } & \multirow{2}{*}{$\begin{array}{l}\text { Weight } \\
(\mathrm{kg})\end{array}$} & \multirow{2}{*}{$\begin{array}{l}\text { Height } \\
(\mathrm{cm})\end{array}$} & \multirow{2}{*}{$\begin{array}{l}B M I \\
\left(k g \cdot m^{-2}\right)\end{array}$} \\
\hline & & $M$ & $F$ & & & \\
\hline Fentanyl & $\begin{array}{l}49.9 \\
(7.5)\end{array}$ & 10 & 0 & $\begin{array}{l}73.2 \\
(5.7)\end{array}$ & $\begin{array}{l}168 \\
(0)\end{array}$ & $\begin{array}{l}25.2 \\
(0.9)\end{array}$ \\
\hline Alfentanil & $\begin{array}{l}49.6 \\
(8.7)\end{array}$ & 9 & 1 & $\begin{array}{l}68.3 \\
(5.7)\end{array}$ & $\begin{array}{l}167 \\
(0)\end{array}$ & $\begin{array}{l}24.5 \\
(2.2)\end{array}$ \\
\hline
\end{tabular}

Mean (SD).

BMI: Body Mass Index.

The flow resistive properties of the equipment (tracheal tubes plus connectors) were calculated using experimental inspiratory flow of $1 \mathrm{~L} \cdot \mathrm{s}^{-1}$ and $100 \%$ oxygen, as described previously. ${ }^{4}$ The relationship between resistive pressure $\left(\mathbf{P}_{\text {res }}\right)$ and flow $(\dot{V})$ was always curvilinear and best fitted by the function $P_{\text {res }}=a \cdot \dot{V}^{b}$, where $a$ is the equipment resistive pressure at $\dot{V}$ of $1 \mathrm{~L} \cdot \sec ^{-1}$ and $b$ is a dimensionless index that describes the shape of the curve. The coefficients $a$ and $b$ obtained for the different tracheal tubes used in the study are described in Table I.

The accuracy of the flow signal was tested by comparing different volumes provided by the ventilator (electronically integrated flow signal) with volumes simultaneously measured by a dry spirometer, within the range of tidal volume (VT) used in the study.

The transducers that measured $P_{t r}$ and $P_{e s}$ were calibrated by applying 5-sec PEEP plateaus of 5, 10, 15, 20 $\mathrm{cm} \mathrm{H}_{2} \mathrm{O}$ during the ventilation of a rubber balloon. The values provided by the electronic display were compared with those measured by the aneroid manometer of the ventilator and with a calibrated pressure transducer Hewlett-Packard 270. Values of flow, $P_{t r}$ and $P_{\text {es }}$ provided differed less than $1 \%$ from those measured by the reference equipment.

Measurements were taken before administration of the opioids, and immediately $(0)$, two, five and ten minutes after injection of fentanyl, $30 \mu \mathrm{g} \cdot \mathrm{kg}^{-1}$ or alfentanil, 120 $\mu \mathrm{g} \cdot \mathrm{kg}^{-1}$. Both drugs were administered via a central venous line. Mean values of three measurements were

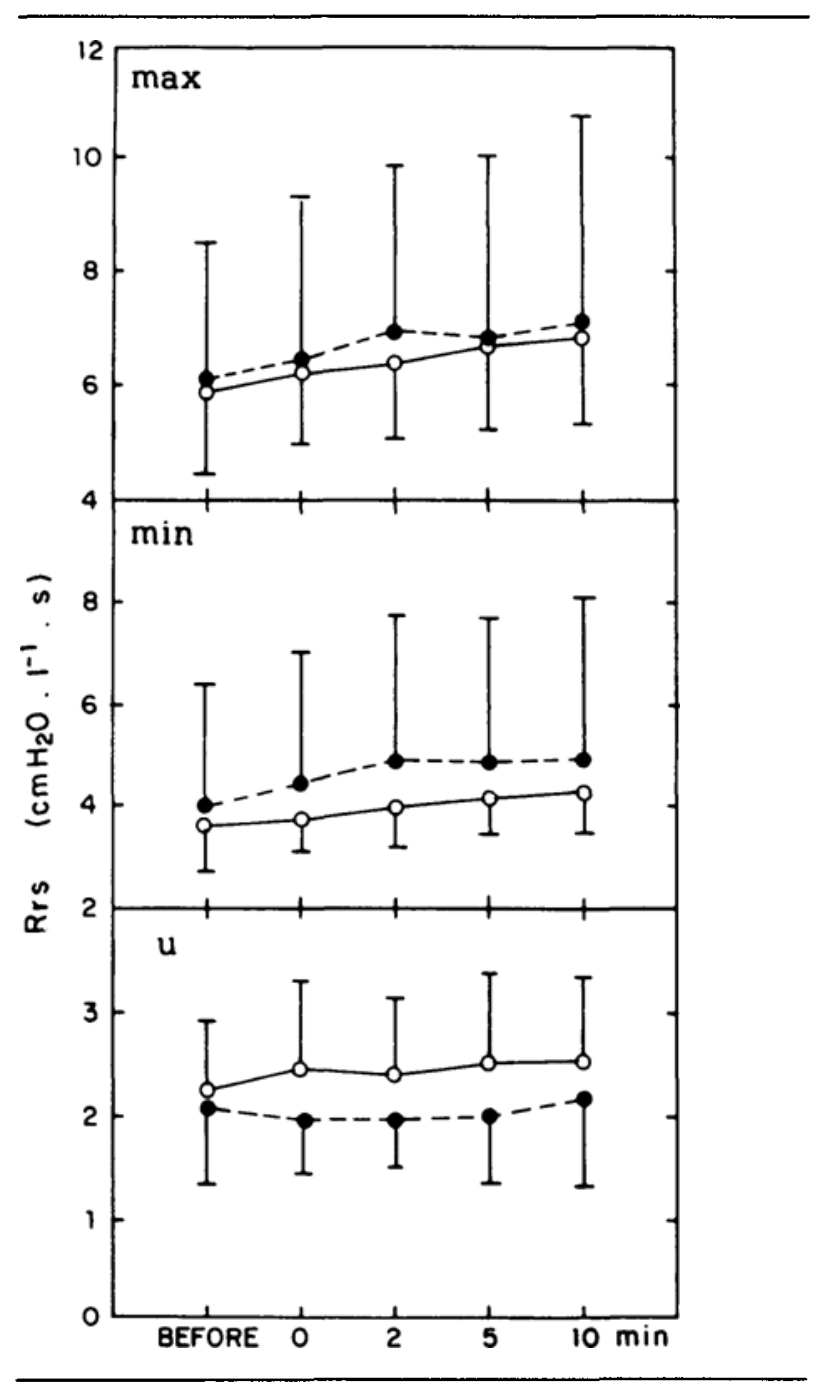

FIGURE 2 Mean values of respiratory system resistances before and after $(O)$ fentanyl and $(\bullet)$ alfentanil. Upper, middle, and lower panels correspond, respectively, to total (max), homogeneous ( $\mathrm{min}$ ) and nonhomogeneous (u) resistances. Bars represent SD.

TABLE III Mean values (SD) of respiratory system resistances before and after (FG) fentanyl and (AG) alfentanil.

\begin{tabular}{|c|c|c|c|c|c|c|}
\hline & \multicolumn{2}{|l|}{$R_{r s, \max }$} & \multicolumn{2}{|l|}{$R_{r s, \min }$} & \multicolumn{2}{|l|}{$R_{r s, u}$} \\
\hline & $F G$ & $A G$ & $F G$ & $A G$ & $F G$ & $A G$ \\
\hline Before & $\begin{array}{c}5.87 \\
(1.42)\end{array}$ & $\begin{array}{c}6.07 \\
(2.43)\end{array}$ & $\begin{array}{c}3.61 \\
(0.90)\end{array}$ & $\begin{array}{c}3.98 \\
(2.41)\end{array}$ & $\begin{array}{c}2.25 \\
(0.66)\end{array}$ & $\begin{array}{c}2.08 \\
(0.74)\end{array}$ \\
\hline $0^{\prime}$ & $\begin{array}{c}6.21 \\
(1.25)\end{array}$ & $\begin{array}{c}6.44 \\
(2.82)\end{array}$ & $\begin{array}{c}3.47 \\
(0.66)\end{array}$ & $\begin{array}{c}4.45 \\
(2.58)\end{array}$ & $\begin{array}{c}2.46 \\
(0.84)\end{array}$ & $\begin{array}{c}1.98 \\
(0.54)\end{array}$ \\
\hline $2^{\prime}$ & $\begin{array}{c}6.39 \\
(1.33)\end{array}$ & $\begin{array}{c}6.95 \\
(2.87)\end{array}$ & $\begin{array}{c}3.97 \\
(0.80)\end{array}$ & $\begin{array}{c}4.86 \\
(2.88)\end{array}$ & $\begin{array}{c}2.41 \\
(0.73)\end{array}$ & $\begin{array}{l}1.98 \\
0.47)\end{array}$ \\
\hline $5^{\prime}$ & $\begin{array}{c}6.68 \\
(1.45)\end{array}$ & $\begin{array}{c}6.87 \\
(3.14)\end{array}$ & $\begin{array}{c}4.16 \\
(0.72)\end{array}$ & $\begin{array}{c}4.85 \\
(2.86)\end{array}$ & $\begin{array}{c}2.52 \\
(0.86)\end{array}$ & $\begin{array}{c}2.01 \\
(0.65)\end{array}$ \\
\hline $10^{\prime}$ & $\begin{array}{c}6.85 \\
(1.50)\end{array}$ & $\begin{array}{c}7.11 \\
(3.64)\end{array}$ & $\begin{array}{c}4.30 \\
(0.82)\end{array}$ & $\begin{array}{c}4.93 \\
(3.18)\end{array}$ & $\begin{array}{c}2.54 \\
(0.81)\end{array}$ & $\begin{array}{c}2.17 \\
(0.84)\end{array}$ \\
\hline
\end{tabular}




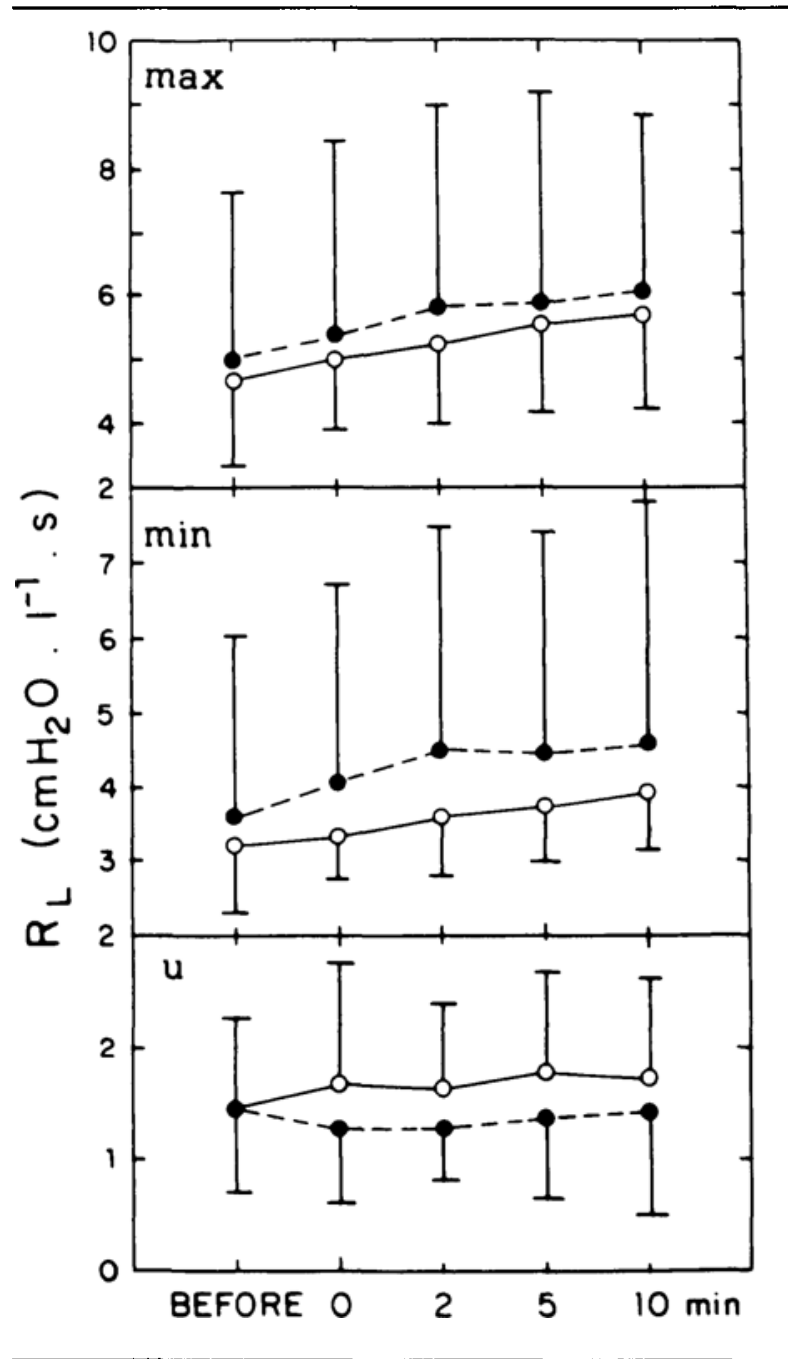

FIGURE 3 Mean values of pulmonary resistances before and after (O) fentanyl and (O) alfentanil. Upper, middle, and lower panels correspond, respectively, to total (max), homogeneous (min) and nonhomogeneous (u) resistances. Bars represent SD.

made at each of the five sampling times and were analysed by profile analysis. ${ }^{6}$ For this purpose we employed the statistical software SAS - statistical analysis system. ${ }^{7}$ The significance level was established at 0.05 .

\section{Results}

Table II describes the subjects studied. Figures 2, 3, 4 and Tables III, IV, V show values (mean \pm SD) of resistance for respiratory system $\left(R_{r s, \max }, R_{r s, m i n}\right.$ and $\left.R_{\mathrm{r}, \mathrm{u}}\right)$, lungs $\left(\mathrm{R}_{\mathrm{L}, \max }, \mathrm{R}_{\mathrm{L} \text {,min }}\right.$ and $\left.\mathrm{R}_{\mathrm{L}, \mathrm{u}}\right)$ and chest wall $\left(R_{w, \max }, R_{w, \min }\right.$ and $\left.R_{w, u}\right)$. Figure 5 and Table VI show values (mean $\pm S D$ ) of $E_{r s}, E_{w}$ and $E_{L}$.

No differences between the effects of fentanyl and alfentanil upon mechanical properties of the respiratory system, lungs and chest wall were demonstrated. Both drugs produced an increase in homogeneous respiratory

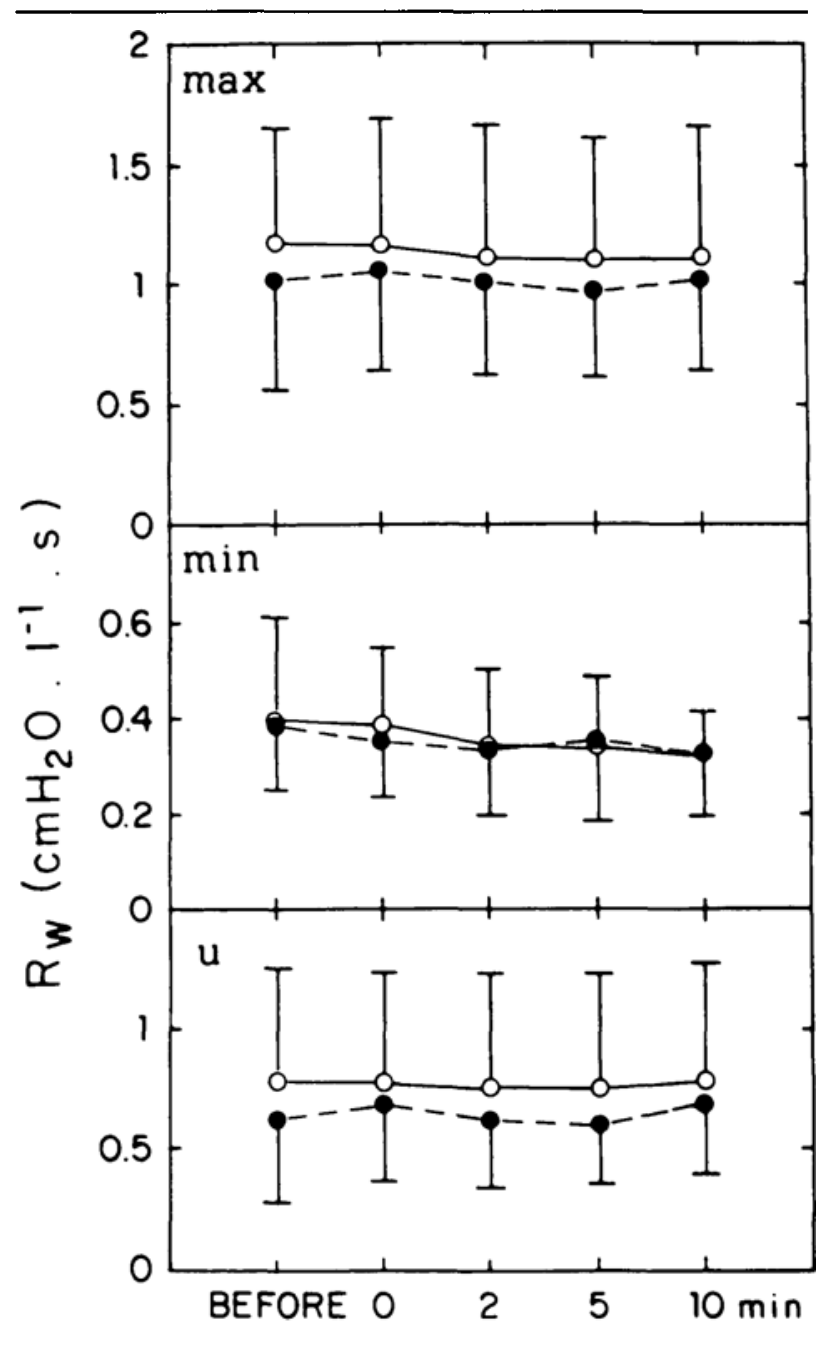

FIGURE 4 Mean values of chest wall resistances before and after $(O)$ fentanyl and $(\Theta)$ alfentanil. Upper, middle, and lower panels correspond, respectively, to total ( $\max$ ), homogeneous (min) and nonhomogeneous (u) resistances. Bars represent SD.

TABLE IV Mean values (SD) of pulmonary resistances before and after (FG) fentanyl and (AG) alfentanil

\begin{tabular}{|c|c|c|c|c|c|c|}
\hline & \multicolumn{2}{|l|}{$R_{L_{\text {max }}}$} & \multicolumn{2}{|l|}{$R_{L \text { min }}$} & \multicolumn{2}{|l|}{$R_{L, u}$} \\
\hline & $F G$ & $A G$ & $F G$ & $A G$ & $F G$ & $A G$ \\
\hline Before & $\begin{array}{c}4.67 \\
(1.35)\end{array}$ & $\begin{array}{c}5.05 \\
(2.55)\end{array}$ & $\begin{array}{c}3.21 \\
(0.91)\end{array}$ & $\begin{array}{c}3.59 \\
(2.45)\end{array}$ & $\begin{array}{c}1.47 \\
(0.80)\end{array}$ & $\begin{array}{c}1.45 \\
(0.73)\end{array}$ \\
\hline $0^{\prime}$ & $\begin{array}{c}5.01 \\
(1.12)\end{array}$ & $\begin{array}{c}5.38 \\
(3.02)\end{array}$ & $\begin{array}{c}3.34 \\
(0.59)\end{array}$ & $\begin{array}{c}4.09 \\
(2.62)\end{array}$ & $\begin{array}{c}1.68 \\
(0.90)\end{array}$ & $\begin{array}{c}1.29 \\
(0.66)\end{array}$ \\
\hline $2^{\prime}$ & $\begin{array}{c}5.26 \\
(1.25)\end{array}$ & $\begin{array}{c}5.84 \\
(3.15)\end{array}$ & $\begin{array}{c}3.62 \\
(0.80)\end{array}$ & $\begin{array}{c}4.53 \\
(2.96)\end{array}$ & $\begin{array}{c}1.64 \\
(0.79)\end{array}$ & $\begin{array}{c}1.31 \\
(0.46)\end{array}$ \\
\hline $5^{\prime}$ & $\begin{array}{c}5.57 \\
(1.38)\end{array}$ & $\begin{array}{c}5.89 \\
(3.32)\end{array}$ & $\begin{array}{c}3.77 \\
(0.75)\end{array}$ & $\begin{array}{c}4.49 \\
(2.94)\end{array}$ & $\begin{array}{c}1.80 \\
(0.91)\end{array}$ & $\begin{array}{c}1.40 \\
(0.71)\end{array}$ \\
\hline $10^{\prime}$ & $\begin{array}{c}5.73 \\
(1.48)\end{array}$ & $\begin{array}{c}6.08 \\
(3.79)\end{array}$ & $\begin{array}{c}3.97 \\
(0.81)\end{array}$ & $\begin{array}{c}4.62 \\
(3.22)\end{array}$ & $\begin{array}{c}1.75 \\
(0.91)\end{array}$ & $\begin{array}{c}1.45 \\
(0.91)\end{array}$ \\
\hline
\end{tabular}




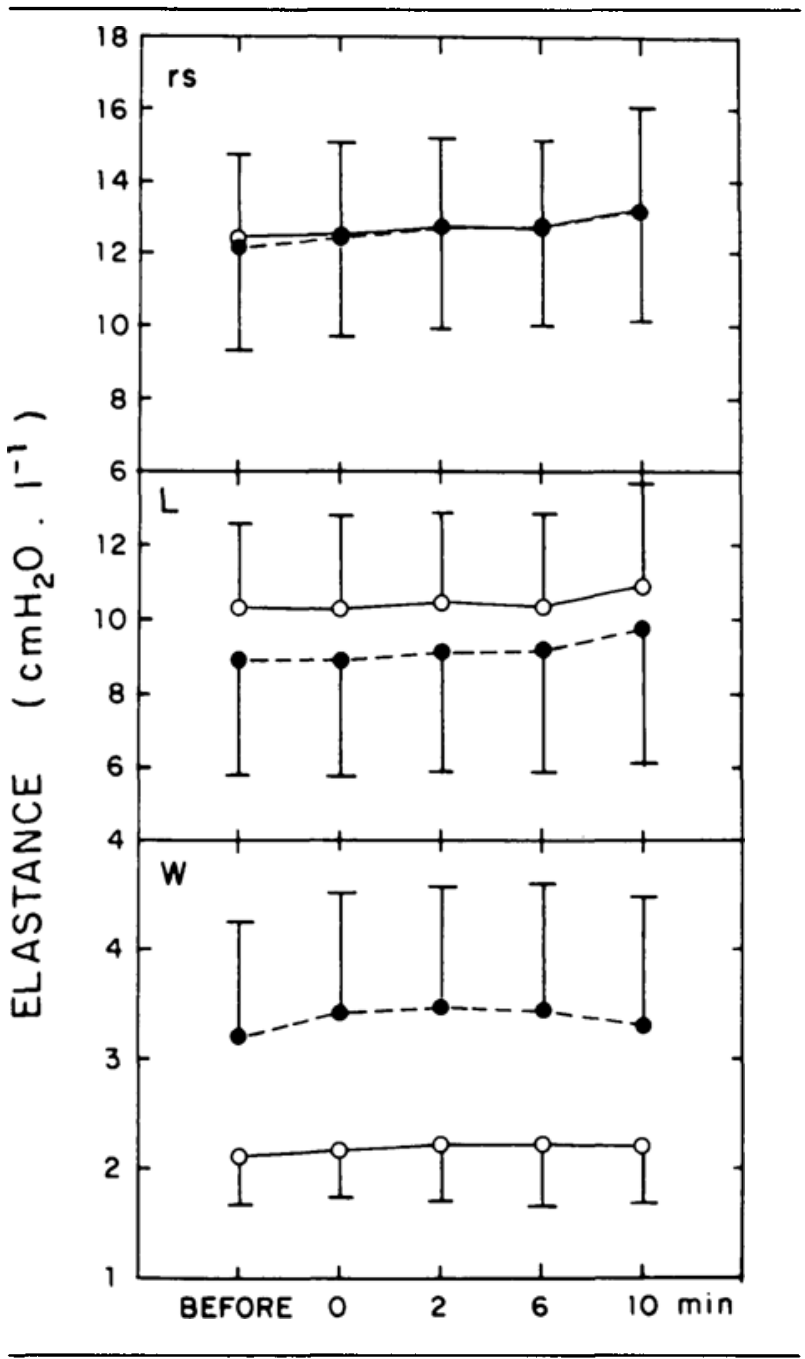

FIGURE 5 Mean values of elastances before and after $(O)$ fentanyl and $(\Theta)$ alfentanil. Upper, middle, and lower panels correspond, respectively, to respiratory system (rs), pulmonary (L) and chest wall (w) elastances. Bars represent SD.

system resistance $\left(R_{r s, m i n}\right)$ at two, five and ten minutes, compared with control. Fentanyl and alfentanil also produced increases in homogeneous pulmonary resistance $\left(R_{L, m i n}\right)$ and in respiratory system elastance $\left(E_{r s}\right)$ at two, five and ten minutes. For both drugs, increases in pulmonary resistance $\left(R_{L, \max }\right)$ occurred at five and ten minutes, and in pulmonary elastance $\left(E_{L}\right)$ at ten minutes.

The elastic-resistive properties of chest wall did not present significant changes after injection of both drugs.

\section{Discussion}

The changes in respiratory mechanics induced by specific intravenous anaesthetic drugs have received little attention. In this study the values of $\mathrm{E}_{\mathrm{rs}}$ before the opioids were similar to those described in studies performed in anaesthetized subjects. ${ }^{8-10}$ The $E_{r s}$ was $12.46 \pm 2.26$ and 12.16
TABLE $V$ Mean values (SD) of chest wall resistances before and after (FG) fentanyl and (AG) alfentanil

\begin{tabular}{|c|c|c|c|c|c|c|}
\hline & \multicolumn{2}{|l|}{$R_{w, \max }$} & \multicolumn{2}{|l|}{$\boldsymbol{R}_{w, \min }$} & \multicolumn{2}{|l|}{$R_{w, u}$} \\
\hline & $F G$ & $A G$ & $F G$ & $A G$ & $F G$ & $A G$ \\
\hline Before & $\begin{array}{c}1.18 \\
(0.57)\end{array}$ & $\begin{array}{c}1.02 \\
(0.46)\end{array}$ & $\begin{array}{c}0.40 \\
(0.21)\end{array}$ & $\begin{array}{c}0.39 \\
(0.14)\end{array}$ & $\begin{array}{c}0.78 \\
(0.48)\end{array}$ & $\begin{array}{c}0.63 \\
(0.35)\end{array}$ \\
\hline $0^{\prime}$ & $\begin{array}{c}1.17 \\
(0.52)\end{array}$ & $\begin{array}{c}1.06 \\
(0.42)\end{array}$ & $\begin{array}{c}0.39 \\
(0.16)\end{array}$ & $\begin{array}{c}0.36 \\
(0.14)\end{array}$ & $\begin{array}{c}0.78 \\
(0.46)\end{array}$ & $\begin{array}{c}0.69 \\
(0.32)\end{array}$ \\
\hline $2^{\prime}$ & $\begin{array}{c}1.12 \\
(0.55)\end{array}$ & $\begin{array}{c}1.01 \\
(0.39)\end{array}$ & $\begin{array}{c}0.35 \\
(0.15)\end{array}$ & $\begin{array}{c}0.34 \\
(0.14)\end{array}$ & $\begin{array}{c}0.76 \\
(0.48)\end{array}$ & $\begin{array}{c}0.63 \\
(0.28)\end{array}$ \\
\hline $5^{\prime}$ & $\begin{array}{c}1.11 \\
(0.51)\end{array}$ & $\begin{array}{c}0.97 \\
(0.36)\end{array}$ & $\begin{array}{c}0.35 \\
(0.14)\end{array}$ & $\begin{array}{c}0.36 \\
(0.15)\end{array}$ & $\begin{array}{c}0.76 \\
(0.48)\end{array}$ & $\begin{array}{c}0.61 \\
(0.25)\end{array}$ \\
\hline $10^{\prime}$ & $\begin{array}{c}1.12 \\
(0.55)\end{array}$ & $\begin{array}{c}1.03 \\
(0.39)\end{array}$ & $\begin{array}{c}0.33 \\
(0.09)\end{array}$ & $\begin{array}{c}0.33 \\
(0.13)\end{array}$ & $\begin{array}{c}0.79 \\
(0.50)\end{array}$ & $\begin{array}{c}0.71 \\
(0.30)\end{array}$ \\
\hline
\end{tabular}

$\pm 2.80 \mathrm{cmH}_{2} \mathrm{O} \cdot \mathrm{L}^{-1}$ for the fentanyl and alfentanil groups respectively. Higher values for $E_{r s}$ have been described elsewhere although some studies assessed patients with pulmonary or valvular diseases. ${ }^{8,11,12}$ Factors such as body weight, position and type of ventilation also influence respiratory mechanics. ${ }^{8}$

Muscle relaxants have no influence on mechanical respiratory properties, provided they do not increase plasma histamine concentration. ${ }^{4,8.9}$

There are few reports of $E_{w}$ in anaesthetized subjects but values of $E_{w}$ of $0.63,2.06$ and $6.06 \mathrm{cmH}_{2} \mathrm{O} \cdot \mathrm{L}^{-1}$ have been reported. ${ }^{9,13,14}$ In the present investigation $E_{w}$ was $2.11 \pm 0.43 \mathrm{cmH}_{2} \mathrm{O} \cdot \mathrm{L}^{-1}$ and $3.2 \pm 1.04 \mathrm{cmH}_{2} \mathrm{O} \cdot \mathrm{L}^{-1}$ for the fentanyl and alfentanil groups, respectively. The groups were statistically different before the use of the opioid and this can be explained by the individual variance of $E_{w}$. For subsequent statistical analysis of the effects of both drugs on $E_{w}$, the $E_{w}$ measured before each opioid was considered as a covariable.

Values of $E_{\mathrm{rs}}, \mathrm{E}_{\mathrm{L}}$ and $\mathrm{E}_{\mathrm{w}}$ after anaesthetic induction and before opioid administration were already higher than those obtained from conscious subjects. ${ }^{8,10,15}$ Elastance can be increased during anaesthesia by many mechanisms, such as decrease of functional residual capacity and subsequent development of atelectasis, pulmonary vascular congestion and accumulation of interstitial fluid, changes in inspired gas distribution, disfunction in surfactant substance and by the action of anaesthetic agents upon airway smooth muscles or even a combination of these. ${ }^{8}$

The fact $E_{L}$ increased only ten minutes after opioid administration makes it difficult to believe that the opioid lung sequestration provoked changes in the elastic properties of the respiratory system. As both drugs present an immediate period of lung sequestration after $i v$ injection, ${ }^{2}$ earlier changes in lung elastance would be expected. On 
TABLE VI Mean values (SD) of elastances before and after (FG) fentanyl and (AG) alfentanil

\begin{tabular}{|c|c|c|c|c|c|c|}
\hline & \multicolumn{2}{|l|}{$E_{r s}$} & \multicolumn{2}{|l|}{$E_{w}$} & \multicolumn{2}{|l|}{$E_{L}$} \\
\hline & $F G$ & $A G$ & $F G$ & $A G$ & $F G$ & $A G$ \\
\hline Before & $\begin{array}{l}12.46 \\
(2.26)\end{array}$ & $\begin{array}{l}12.16 \\
(2.80)\end{array}$ & $\begin{array}{c}2.11 \\
(0.43)\end{array}$ & $\begin{array}{c}3.2 \\
(1.04)\end{array}$ & $\begin{array}{l}10.35 \\
(2.22)\end{array}$ & $\begin{array}{c}8.96 \\
(3.14)\end{array}$ \\
\hline $0^{\prime}$ & $\begin{array}{l}12.52 \\
(2.56)\end{array}$ & $\begin{array}{l}12.45 \\
(2.76)\end{array}$ & $\begin{array}{c}2.18 \\
(0.43)\end{array}$ & $\begin{array}{c}3.44 \\
(1.07)\end{array}$ & $\begin{array}{l}10.33 \\
(2.50)\end{array}$ & $\begin{array}{l}9.0 \\
(3.20)\end{array}$ \\
\hline $2^{\prime}$ & $\begin{array}{l}12.78 \\
(2.42)\end{array}$ & $\begin{array}{l}12.72 \\
(2.79)\end{array}$ & $\begin{array}{c}2.24 \\
(0.50)\end{array}$ & $\begin{array}{c}3.50 \\
(1.07)\end{array}$ & $\begin{array}{l}10.54 \\
(2.38)\end{array}$ & $\begin{array}{c}9.22 \\
(3.29)\end{array}$ \\
\hline $5^{\prime}$ & $\begin{array}{l}12.69 \\
(2.42)\end{array}$ & $\begin{array}{l}12.77 \\
(2.74)\end{array}$ & $\begin{array}{c}2.24 \\
(0.55)\end{array}$ & $\begin{array}{c}3.48 \\
(1.14)\end{array}$ & $\begin{array}{l}10.45 \\
(2.45)\end{array}$ & $\begin{array}{c}9.29 \\
(3.30)\end{array}$ \\
\hline $10^{\prime}$ & $\begin{array}{l}13.20 \\
(2.83)\end{array}$ & $\begin{array}{l}13.19 \\
(3.05)\end{array}$ & $\begin{array}{c}2.23 \\
(0.51)\end{array}$ & $\begin{array}{c}3.36 \\
(1.13)\end{array}$ & $\begin{array}{l}10.97 \\
(2.77)\end{array}$ & $\begin{array}{c}9.83 \\
(3.61)\end{array}$ \\
\hline
\end{tabular}

the other hand, fentanyl has a longer period of sequestration in lung tissue ${ }^{2}$ and we were not able to find a difference between both opioids in respect to effects over mechanical respiratory properties. This supports the idea that lung sequestration is not a determining factor for the changes in elastic properties of the respiratory system. We were unable to explain why $\mathrm{E}_{\mathrm{rs}}$ changed two, five and ten minutes after drug administration while $\mathrm{E}_{\mathrm{L}}$ changed only at ten minutes despite no change in $\mathrm{E}_{\mathrm{w}}$ during the study.

Changes in airway resistance could explain the variation in elastance. After anaesthetic induction and before opioid administration, we found values for respiratory system resistance $\left(R_{r s, \max }\right)$ of $5.87 \pm 1.42$ and $6.07 \pm 2.43$ $\mathrm{cmH}_{2} \mathrm{O} \cdot \mathrm{L}^{-1} \cdot$ sec for the fentanyl and alfentanil groups. These findings are very similar to other investigations that studied anaesthetized subjects. ${ }^{16-20}$ Some authors found values of $R_{r s, \max }$ as 7.9 and $8.8 \mathrm{cmH}_{2} \mathrm{O} \cdot \mathrm{L}^{-1} \cdot \mathrm{sec},{ }^{21-22}$ which were larger than in the present study, although they did not discuss the resistance of the equipment or the level of hypocarbia obtained for establishment of apnoea. Both

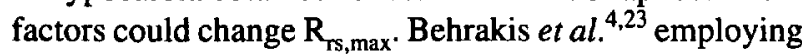
a method similar to the present study observed smaller values for $R_{r s, \max }$. The presence of lung disease in subjects studied and different ventilatory settings of the ventilator may also explain discrepancies described in literature. ${ }^{24}$

Pulmonary resistances $R_{\mathrm{L}, \max }$ of $4.67 \pm 1.35$ and 5.05 $\pm 2.55 \mathrm{cmH}_{2} \mathrm{O} \cdot \mathrm{L}^{-1} \cdot \mathrm{sec}$ for fentanyl and alfentanil groups, assessed after induction and before opioids, were also similar to those described in literature, which ranged from 4.9 to $5.2 \mathrm{cmH}_{2} \mathrm{O} \cdot \mathrm{L}^{-1} \cdot \mathrm{sec}^{8,25}$ Values of $\mathrm{R}_{\mathrm{L}, \max }$ slightly larger $6.1 \mathrm{cmH}_{2} \mathrm{O} \cdot \mathrm{L}^{-1} \cdot \mathrm{sec}$ and smaller, 3.9 and $3.7 \mathrm{cmH}_{2} \mathrm{O} \cdot \mathrm{L}^{-1} \cdot \mathrm{sec}$ have also been described. ${ }^{8}$ In the first study equipment resistance was not considered and in the second study the use of a bronchodilating anaesthetic agent, $1 \%$ and $2 \%$ isoflurane may again explain the discrepancies found. Behrakis et al. ${ }^{4}$ found even smaller values for $\mathrm{R}_{\mathrm{L} \text {,max }}, 0.8 \mathrm{cmH}_{2} \mathrm{O} \cdot \mathrm{L}^{-1} \cdot \mathrm{sec}$, and they had difficulties in explaining their results. Factors such as age, use of atropine or halogenated anaesthetics, and the methods employed were suggested but no clear explanation was found.

Our findings for $\mathrm{R}_{\mathrm{w} \text {,max }}$ after induction and before opioids were similar to the only investigation found where this variable was studied during anaesthesia. ${ }^{4}$ No other study has assessed the effects of general anaesthetics on the two subcomponents of resistance chest wall, $R_{w, \min }$ and $\mathrm{R}_{\mathrm{w}, \mathrm{u}}$.

In our patients, the relationship between $R_{r s, u}$ and $R_{r s, m i n}$ before opioids was around $30 \%$ which is acceptable for normal subjects. Patients with ARDS present higher values for $R_{r s, u}$, which increases the relationship. ${ }^{24}$

Similarly in studying the respiratory elastic properties, there were no differences between fentanyl and alfentanil, conceming the flow resistive properties of the respiratory system, lungs and chest wall.

Pulmonary resistance $\left(\mathrm{R}_{\mathrm{L} \text {, max }}\right)$ increased at five and ten minutes after both drugs. This may explain the higher values of pulmonary elastance observed at ten minutes. The non-homogeneous subcomponent of respiratory system and pulmonary resistances $\left(R_{r s, \min }\right.$ and $\left.R_{L, m i n}\right)$ presented similar variation of $E_{r s}$, or showed increases at two, five and ten minutes. The increase of this subcomponent of resistance may explain the variation of $\mathrm{E}_{\mathrm{rs}}$. Based upon previous studies ${ }^{5,26}$ the homogeneous subcomponent of resistance $\left(R_{\text {min }}\right)$ is associated to the central portion of airways, or those where there are smooth muscles. Any drug promoting contraction of those muscles may increase $\mathbf{R}_{\mathrm{rs} \text {,min }}$ or $\mathbf{R}_{\mathrm{L}, \min }$, and consequently $\mathrm{E}_{\mathrm{rs}}$.

Parasympathetic pathways play an important role on the tone of respiratory smooth muscles. ${ }^{27}$ Opioids used in moderate to large doses, as in the present study, may decrease the amount of circulating catecholamines making the autonomic nervous system balance tend to cholinergic influence. Opioid cholinergic action can increase bronchial smooth muscle tone, ${ }^{2,28}$ even when small doses of opioids are used. ${ }^{29}$ Opioid histamine release could also explain the increase of $R_{r s}$, although histamine liberation has not been demonstrated for fentanyl and alfentanil.

Both the non-homogeneous subcomponent of respiratory $\left(\mathrm{R}_{\mathrm{rs}, \mathrm{u}}\right)$ and pulmonary $\left(\mathrm{R}_{\mathrm{L}, \mathrm{u}}\right)$ resistances, associated with mechanisms occurring within lung tissue, did not change after either opioid. Thus, the opioids did not act at the lung tissue level, and the lung sequestration did not affect flow-resistive characteristics of the respiratory system. Chest wall resistances did not change after either opioid and, in the conditions of the present investigation, they do not contribute to the variation of respiratory resistance and elastance.

We concluded that there is no difference between 
fentanyl and alfentanil with regard to the effects on mechanical properties of respiratory system. The changes observed in elastance and resistance of the respiratory system and lungs might have originated by opioid action or bronchial smooth muscle.

Although we were able to observe changes in some respiratory mechanical properties, they did not cause clinical effects in the patients studied. This might be because we investigated patients with normal lung function. Subjects with pulmonary disease may present different behaviour. It would be helpful to perform further investigations to assess the effects of opioids on the respiratory mechanics of patients with lung disease using the EIOM.

\section{Acknowledgement}

We wish to thank Professor Ruy Vaz Gomide do Amaral of the Department of Anaesthesiology for his stimulation throughout this study.

\section{References}

1 Milic-Emili J, Robatto FM, Bates JHT. Respiratory mechanics in anaesthesia. Br J Anaesth 1990; 65: 4-12.

2 Taeger K, Weninger E, Schmelzer F, Adt M, Franke N, Peter $K$. Pulmonary kinectics of fentanyl and alfentanil in surgical patients. Br J Anaesth 1988; 61: 425-34.

3 Yasuda I, Hirano T, Yusa T, Satoh M. Tracheal constriction by morphine and fentanyl in man. Anesthesiology 1978; 19: 117-9.

4 Behrakis PK, Higgs BD, Bevan DR, Milic-Emili J. Partioning of respiratory mechanics in halothaneanesthetized humans. J Appl Physiol 1985; 58: 285-9.

5 Bates JHT, Rossi A, Milic-Emili J. Analysis of the behavior of the respiratory system with constant inspiratory flow. J Appl Physiol 1985; 58: 1840-8.

6 Timm NH. Two sample profile analysis - multivariate. In: (Ed.). Multivariate analysis with applications in education and psychology. Monterrey; Brooks/Cole Publishing Company, 1975; 237-43.

7 SAS - Statistical Analysis System. User's guide: Statistics, version 6th Edition. Cary, NC: SAS Institute Inc, 1987; 549-640.

8 Redher $K$, Marsh HM. Respiratory mechanics during anesthesia and mechanical ventilation. In: Macklem PT, Mead J (Eds.). Handbook of Physiology. The Respiratory System. Bethesda: American Physiological Society, 1986; 737-852.

9 Westbrook PR, Stubbs SE, Sessler AD, Rehder K, Hyatt $R E$. Effects of anesthesia and muscle paralysis on respiratory mechanics in normal man. J Appl Physiol 1973; 34: 81-6.
10 Hedenstierna $G, M c$ Carthy $C$. Mechanics of breathing gas distribution and FRC at different respiratory frequencies during spontaneous and artificial ventilation. $\mathrm{Br} J$ Anaesth 1975; 47: 706-12.

11 Auler Jr JOC, Zin WA, Caldeira MPR, Cardoso WV, Saldiva $P H N$. Pre and postoperative inspiratory mechanics in ischemic and valvular heart diseases. Chest 1987; 92: 984-90.

12 Larsson A, Jonmarker $C$, Werner $O$. Lung mechanics during upper abdominal surgery. Acta Chir Scand 1989; 155: 329-32.

13 Cheng TO, Godfrey MP, Shepard RH. Pulmonary resistance and state of inflation of lungs in normal subjects and in patients with airway obstruction. J Appl Physiol 1959; 14: 727-32.

14 Rehder K, Mallow JE, Fibuch EE, Krabill DR, Sessler AD. Effects of isoflurane anesthesia and muscle paralysis on respiratory mechanics in normal man. Anesthesiology 1974; 41: 477-85.

15 Hedenstierna $G$. Gas exchange during anaesthesia. $\mathrm{Br} \mathrm{J}$ Anaesth 1990; 64: 507-14.

16 Bergman NA. Properties of passive exhalation in anesthetized subjects. Anesthesiology 1969; 30: 378-87.

17 Daly WJ, Ross JC, Behnke RH. The effects of changes in the pulmonary vascular bed produced by atropine, pulmonary engorgement and positive-pressure breathing on diffusing and mechanical properties of the lungs. J Clin Invest 1963; 42: 1083-94.

18 Don HF, Robson JG. The mechanics of the respiratory system during anesthesia. The effects of atropine and $\mathrm{CO}_{2}$. Anesthesiology 1965; 26: 168-78.

19 Norlander $O$, Herzog $P$, Norden I. Compliance and airway resistance during anesthesia with controlled ventilation. Acta Anaesthesiol Scand 1968; 12: 135-52.

20 Andersen NB, Guia J. Pulmonary function, cardiac status and postoperative course in relation to cardiopulmonary bypass. J Thorac Cardiovasc Surgery 1970; 59: 474-83.

21 Brakensiek AL, Bergman NA. Effects of halothane and atropine on total respiratory resistance in anaesthetized man. Anesthesiology 1970; 33: 341-4.

22 Sechzer $P H$. Effect of hypothermia on compliance and resistance of lung-thorax system in anesthetized man. $J$ Appl Physiol 1958; 13: 53-6.

23 Behrakis PK, Higgs BD, Bayduk A, Zin WA, Milic-Emili, J. Respiratory mechanics during halothane anesthesia and anesthesia-paralysis in humans. J Appl Physiol 1983: 55: 1085-92.

24 Auler Jr JOC, Saldiva PHN, Martins MA. Flow and volume dependence of respiratory mechanics during constant flow ventilation in normal and in adult respiratory failure. Crit Care Med 1990; 18: 1080-6. 
25 Grimby $G$, Hedenstierna $G$, Lofstrom $B$. Chest wall mechanics during artificial ventilation. J Appl Physiol 1975; 38: 576-80.

26 Bates JHT, Baconnier P, Milic-Emili J. A theoretical analysis of interrupter technique for measuring respiratory mechanics. J Appl Physiol 1988; 64: 2204-14.

27 Hirshman CA, Bergman NA. Factors influencing intrapulmonary airway calibre during anaesthesia. $\mathrm{Br} \mathbf{J}$ Anaesth 1990; 65: 30-42.

28 Gentil B, MacQuin-Mavier I, Harf A. Fentanyl-induced airway hyperreactivity in the guinea-pig. Eur $\mathbf{J}$ Pharmacol 1989; 159: 181-5.

29 Cohendy $R$, Laracine $M$, Rebeiere $T$, Calvet $F$, Eledjam $J J$. Effects of fentanyl on pulmonary resistance properties. An occlusion method study. Anesthesiology 1990; 73: A1148. 